BULLETIN Bulletin hispanique

HISPANIQUE Université Michel de Montaigne Bordeaux

116-2 | 2014

Référentialité/autoréférentialité dans le roman

espagnol contemporain : bilan et perspectives

\title{
Juan José Lanz, Nuevos y novísimos poetas en la estela del 68
}

Renacimiento, Sevilla, 2011

Julio Neira

\section{OpenEdition}

Journals

\section{Edición electrónica}

URL: http://journals.openedition.org/bulletinhispanique/3687

DOI: 10.4000/bulletinhispanique.3687

ISBN: 979-10-300-0156-3

ISSN: 1775-3821

Editor

Presses universitaires de Bordeaux

\section{Edición impresa}

Fecha de publicación: 1 diciembre 2014

Paginación: 934-938

ISBN: 978-2-86781-963-6

ISSN: 0007-4640

\section{Referencia electrónica}

Julio Neira, "Juan José Lanz, Nuevos y novísimos poetas en la estela del 68 », Bulletin hispanique [En línea], 116-2 | 2014, Publicado el 16 marzo 2015, consultado el 23 septiembre 2020. URL : http:// journals.openedition.org/bulletinhispanique/3687; DOI : https://doi.org/10.4000/bulletinhispanique. 3687

Este documento fue generado automáticamente el 23 septiembre 2020.

Tous droits réservés 


\title{
Juan José Lanz, Nuevos y novísimos poetas en la estela del 68
}

\author{
Renacimiento, Sevilla, 2011
}

Julio Neira

\section{REFERENCIA}

Juan José LANZ, Nuevos y novísimos poetas en la estela del 68, Sevilla, Renacimiento, 2011, 400 p. colección Iluminaciones, 66. - ISBN-13: 978-84-8472-605-0

1 Está sobradamente acreditado que el profesor de la Universidad del País Vasco Juan José Lanz es uno de los mayores especialistas en el estudio de la poesía española de la segunda mitad del siglo XX. Así lo ratifican sus solventes monografías sobre algunos de los hitos más significativos de esa época, como sus numerosos trabajos sobre Blas de Otero, reunidos en el volumen Alas de cadenas (Sevilla, Renacimiento, 2008); sobre la poesía del medio siglo, periodo que trató en Las palabras gastadas (Sevilla, Renacimiento, 2009) y en Conocimiento y comunicación. Textos para una polémica poética en el medio siglo (1950-1963) (Palma de Mallorca, Universitat de les Illes Balears, 2009); sobre la más reciente surgida en los años ochenta, que analizó en La poesía durante la Transición y la generación de la Democracia (Madrid, Devenir, 2007); y, sobre todo, sus estudios acerca de la poesía originada en el plazo comprendido entre 1963 y 1977, que se identifica con la fecha de 1968 por los acontecimientos sociales y políticos ocurridos ese año. Etapa a la que dedicó primero su tesis doctoral, Introducción al estudio de la generación poética española de 1968. Elementos para la elaboración de un marco histórico-crítico en el periodo 1962-1977 (Bilbao, Universidad del País Vasco, 2000), y diversos trabajos sobre las claves de su escritura, La llama en el laberinto. Poesía y poética en la generación del 68 (Mérida, Editora Regional de Extremadura, 1994) y algunas de sus revistas y grupos: Marejada: historia de un grupo literario (Cádiz, Quorum, 1996), Páginas del 68. Revistas poéticas juveniles (1962-1977) (Salamanca, Junta de Castilla y León, 2007), La revista Claraboya (1963-1968): Un episodio fundamental en la renovación poética de los años sesenta (Madrid, UNED, 2005), 
Antorcha de paja. Revista de Poesía (1973-1983). Heterodoxia y canon en la poesía española durante la Transición (Madrid, Devenir, 2012). Debe consignarse además su labor como editor de la Antología de la poesía española 1960-1975 (Madrid, Espasa Calpe, 1997) y de algunos de sus poetas más significativos, como Luis Alberto de Cuenca (Poesía. 1979-1996, Madrid, Cátedra, 2006), Diego Jesús Jiménez (Bajorrelieve. Itinerario para náufragos, Madrid, Cátedra, 2001) o Agustín Delgado (Espíritu áspero. Poesía reunida, Madrid, Trama, 2010). A todo ello se suman sus innumerables artículos en las principales revistas de la especialidad, cuya relación harían inacabable esta reseña.

2 La monografía que comentamos, Nuevos y novísimos poetas en la estela del 68 no sólo viene a ratificar la excelencia de esa ingente actividad investigadora y su dominio de la ya abundante bibliografía especializada, sino que supone un paso más en la evaluación exigente pero ponderada de un momento estéticamente convulso y ecléctico como pocos en nuestra historia poética reciente: una poesía homogénea en su voluntad rupturista con la escrita por las generaciones anteriores, aunque de muy variadas soluciones estéticas a similares planteamientos teóricos; que si debió a técnicas propias del marketing -cuya irrupción fue también signo de los tiempos- buena parte de su posición dominante en los primeros años setenta, a esa especie de pecado original debió también una contestación permanente desde sus orígenes en el ámbito de la poesía española. En todo caso, nos hallamos ante el regreso de un reputado experto a su tema de estudio predilecto, lo que hace de este conjunto de estudios un magnífico y actualizado compendio sobre las claves históricas, sociales y estéticas de esta época de la poesía contemporánea.

3 Este volumen consta de dos partes. Los cuatro capítulos de la primera abordan en su conjunto el fenómeno de la poesía joven y la cosmovisión de los poetas sesentayochistas desde planteamientos teóricos generales, para estudiar en los seis textos de la segunda manifestaciones particulares de algunos de los autores más característicos del periodo. Pero ese análisis de textos significativos por razones diversas viene precedido por una rigurosa caracterización de los aspectos comunes que construyen un marco periodológico y contextualizador de gran solvencia metodológica. El capítulo inicial, «Nueva poesía y novísimos poetas a la altura de 1968» establece pautas de estudio decisivas para acabar con el mito reduccionista de los novísimos y abrir el campo de observación a otros autores de poética muy diversa a la de aquellos Nueve novísimos poetas españoles antologados en 1970 por Castellet. O dicho de otro modo: desvela el sectarismo estético y el reduccionismo canónico de aquella famosa antología, de la que recién aparecida ya quisieron desentenderse sus protagonistas.

Lanz explora el espacio cultural común en el que surge la nueva poesía de los sesenta, el contexto de la Posmodernidad y el concepto de ruptura estética que condiciona esa y las demás antologías del momento, y define con precisión el aspecto central del debate crítico, que no fue a su juicio el compromiso del poeta con la realidad social -sobre cuya necesidad no había discusión-, sino sus estrategias y su sentido en una sociedad neocapitalista y desarrollista como era ya la española de mediados de esa década, plenamente consolidada en los inicios de la siguiente.

5 Desde sus primeros trabajos sobre el tema Lanz ha fijado en 1966-1967 el momento de eclosión de la entonces llamada «nueva poesía española», que manifestaba una decidida voluntad de ruptura con la poesía anterior, siendo sus jalones más destacados los libros La ciudad de Diego Jesús Jiménez (1965) y Preludios a una noche total de Antonio Colinas (1969); de manera que rechaza la denominación Generación de los 70 y el determinismo 
de la antología de Castellet para preferir la de Generación de 1968 por sus vínculos iniciales con las inquietudes políticas y sociales que desembocaron en ese año en las revueltas revolucionarias de Praga, París y California cuyo paradigma se diseminó por todo el mundo occidental y resultaron decisivas para la profunda transformación cultural de la sociedad.

6 Las primeras manifestaciones de una nueva poesía las documenta Lanz en la selección de poesía universitaria que José-Miguel Ullán publica en 1965 en la revista malagueña Caracola, a la que seguirían los números antológicos de la nueva generación de la leonesa Claraboya en 1966 y 1967. En este año aparecen ya la primera Antología de la joven poesía española de Enrique Martín Pardo y Doce jóvenes poetas españoles de Francisco J. Carrillo en El Bardo, colección de referencia dirigida por José Batlló, que un año después publica Antología de la nueva poesía española, que difunden los nombres de Gimferrer, Ullán, Vázquez Montalbán, Guillermo Carnero, Agustín Delgado, José María Álvarez, Jenaro Talens, Juan Luis Panero, Marcos Ricardo Barnatán, etc. De modo que la de Castellet no fue ni mucho menos la primera, aunque sus encarnizados críticos la elevaron a un rango tan alto que convirtieron su propuesta estética en casi único referente de la época, eclipsando las distintas y variadas alternativas del común rechazo del realismo social. Y aunque pronto los propios novísimos renegaron del culturalismo y del manierismo que Castellet había presentado como rasgo predominante en detrimento de los demás componentes de su estética, la simplificación nominalista perpetuó ese marbete y esa antología como elemento caracterizador de toda la generación.

7 A desterrar ese encasillamiento están dedicadas páginas esclarecedoras de este volumen. En ellas Juan José Lanz establece como núcleo fundamental de la poética de estos autores su concepción de que la poesía debe desentenderse de una realidad en la que nunca podrá intervenir ni transformar, y centrarse en la creación de una realidad autónoma por medio del único elemento capaz de ello: el lenguaje. De manera que el poema se convierte en un ejercicio esencialmente lingüístico, y la forma se equipara al contenido. También señala Lanz que algunos autores de promociones anteriores, conscientes de las limitaciones de la poesía realista habían iniciado ese mismo camino por la misma época. Por ejemplo, añadimos nosotros, José Manuel Caballero Bonald en la sección «Nuevas situaciones» de su libro Vivir para contarlo (1969), que reúne poemas fechados entre 1964 y 1968. De ese principio de realidad autónoma se derivaron algunos efectos de singular importancia. El abandono de racionalismo poético conllevó el retorno a fórmulas del vanguardismo histórico de los años veinte, bien sea el experimentalismo -esos son los años del auge de la poesía visual-, el surrealismo e incluso el simbolismo, corrientes todas que tuvieron sus cultivadores en uno $u$ otro momento a lo largo de la trayectoria generacional. Y por la vía de la autorreferencialidad del poema se llegó al culturalismo, que a su vez generó una abundante corriente de metapoesía, otra igualmente intensa de la llamada poética del silencio e, intentando una tercera vía, la denominada poesía dialéctica que pretendió establecer el grupo Claraboya.

8 Si algo caracterizó esa nueva poesía fue su mutabilidad -no en vano nacía como reacción a una poética que juzgaban anquilosada- y su rápida evolución. Hacia 1970 se constata ya el desencanto ante las posiciones radicales iniciales -que se revelan tan inútiles para combatir la dictadura franquista como las del realismo social-; y al tiempo se producen la consolidación del arquetipo novísimo que genera una legión de 
imitadores, la retirada de los novísimos originales a posiciones de retaguardia y la contestación al nuevo poder poético desde posiciones discordantes, que descubren en la poesía experiencial de la generación anterior una tradición válida, o bien incorporan nuevas poéticas alternativas que dispersan la voluntad iconoclasta y atenúan su eficacia, lo que facilita su asimilación por las instancias institucionales. En todo caso, Lanz aprecia en torno a 1973 una profunda crisis y el replanteamiento del desarrollo y las tendencias dominantes hasta entonces. A partir de 1974 se observan indicios de una nueva renovación estética, que cuajará definitivamente a partir de 1977 con la recuperación de autores silenciados hasta entonces, nuevos autores y corrientes muy diversas. Se ha iniciado la Transición política, que tendrá sus propias fórmulas poéticas y su nueva oleada de jóvenes poetas.

9 Tras este marco referencial, los siguientes capítulos de este libro -que pese a definirse «plural y polifónico» (pág. 9) es bastante homogéneo y coherente- profundizan en aspectos clave de ese momento poético, como la idea de ruptura inaplazable con los presupuestos del realismo como núcleo generador de su impulso, más allá de la diferencia de caminos elegidos para expresarla; el papel determinante que tuvo José María Castellet como dinamizador de la operación de relaciones públicas -oportuna y oportunista- que fue Nueve novísimos, aunque en su diseño y fundamentación se apreciara la pluma de Gimferrer, y las circunstancias que explican su génesis y su éxito; así como las nuevas fórmulas con que estos poetas expresaron su compromiso con la realidad y su oposición a la dictadura, en ocasiones de tal sutileza conceptual que fueron acusados de autismo político.

De lo panorámico a lo específico, tras esa primera parte histórico-crítica Lanz analiza en la segunda algunos ejemplos concretos de textos muy significativos de la lírica generacional para documentar sus diversas perspectivas estéticas. Así, «La búsqueda de una identidad a través de la escritura que se manifiesta como su constante pérdida» (pág. 174) en el poema «Mazurca en este día» del libro Arde el mar de Pere Gimferrer, sus numerosas referencias textuales e históricas y sus modelos Eliot, Pound y Perse. También estudia la práctica de la metapoesía por Guillermo Carnero en poemas de sus libros El sueño de Escipión y Variaciones y figuras sobre un tema de La Bruyère que surge, como la poética del silencio, «de la concepción de la poesía como un enfrentamiento entre realidad y lenguaje, y nace ante la constatación del fracaso del lenguaje poético para comunicar una experiencia vivida, la realidad» (pág. 186).

11 Uno de los poetas más diferentes y personales de los surgidos en esos años fue Diego Jesús Jiménez, autor de cinco libros fundados en una "cosmovisión estética compacta», a juicio de Lanz, cuya evolución -de La ciudad (1965) a Itinerario para náufragos (1996)- al margen de las modas estudia como resultado de una «concepción temporalista de la poesía, deudora de la tradición barroca, a través de una dicción irracionalista que se proyecta en una voluntad crítica sobre la realidad» (pág. 246) en un capítulo que sintetiza con singular precisión la especificidad de este poeta conquense voluntariamente alejado de la parafernalia literaria cuya obra, no obstante, fue reconocida con los principales premios de poesía (entre otros el Adonáis en 1964 y el Premio Nacional de Literatura en 1968 y 1997).

En textos de Jaime Siles rastrea Lanz el recorrido en esos años de la poética del silencio hasta su punto extremo alcanzado en Música de agua (1983), casi en el límite de una escritura del vacío o una escritura vacía como espacio desierto donde el lenguaje se desprende de sus connotaciones de poder con la voluntad de dar paso a un nuevo 
lenguaje depurado en el inicio de un nuevo tiempo histórico y, claro está, un nuevo ciclo poético. El análisis de dos poemas de Luis Alberto de Cuenca permite a Lanz considerar el fenómeno de la intertextualidad en la poesía de esa época-que mantiene en la actual una fértil presencia- y la exuberancia con que se manifiesta en este autor, filólogo, traductor entre otras capacidades, como su probada cinefilia o su éxito como letrista de canciones populares. Tal vez por eso sus poemas se convierten en auténticos palimpsestos donde conviven hipotextos de la literatura grecolatina, la artúrica, la medieval, las grandes obras universales, los textos surrealistas, el cine -sobre todo el negro, pero también el norteamericano más comercial-, el cómic, la Historia, etc., con una «compleja tipología de juegos intertextuales, desde transformaciones serias (no paródicas), como la traducción y la transliteración, falsas traducciones, transestilizaciones, transposiciones formales, hasta transmotivaciones serias y paródicas, imitaciones burlescas, etc.» (pág. 312).

Por fin, el libro se cierra con el estudio de Historia natural (1987) del asturiano Víctor Botas (1945-1994), otro poeta muy personal, perteneciente a una segunda promoción generacional del 68, en la que podemos encuadrar también a Miguel d'Ors, José Luis García Martín, Jesús Munárriz, Eloy Sánchez Rosillo, etc., que están de vuelta del culturalismo novísimo -en grave crisis desde finales de los setenta- cuyo exceso denuncian como manierismo autoreferencial y redundante, aunque su obra no dejara de tener una indudable raigambre cultural. En este libro, que resultó culminación de una obra truncada por la temprana desaparición de su autor, halla Juan José Lanz una práctica de la metapoesía y la intertextualidad a la que la autoironía y el ludismo elevan al rango de auténtica sátira social. El cuestionamiento del sistema de valores a través de la relectura de la Historia y la Literatura, donde escritura y lectura se confunden, acaba socavando los fundamentos del lenguaje de poder mediante una poética que él denomina «de la incertidumbre», muy adecuada para un momento de tránsito entre una época obsoleta y otra que emerge y por eso mismo precisaba ser cuestionada desde su origen.

En suma, tanto su planteamiento de conjunto y su exposición de conexiones contextuales históricas, sociales o estrictamente estéticas, como sus penetrantes análisis textuales que los ejemplifican hacen de Nuevos y novísimos poetas en la estela del 68 una herramienta inexcusable para el cabal conocimiento de esa etapa de la poesía española contemporánea, agitada y controvertida en lo externo pero intensamente rica en soluciones formales y cuyo influjo posterior dista mucho de poder darse por concluido.

\section{AUTORES}

\section{JULIO NEIRA}

Universidad Nacional de Educación a Distancia 